\title{
Nitrogen application at the booting stage affects 2-acetyl-1-pyrroline, proline, and total nitrogen contents in aromatic rice
}

\author{
Zhaowen Mo1, 2, Umair Ashraf ${ }^{1,3}$, Yongjian Tang ${ }^{1,2}$, Wu Li ${ }^{4}$, Shenggang Pan ${ }^{1,2}$, Meiyang Duan ${ }^{1,2}$, \\ Hua Tian ${ }^{1,2}$, and Xiangru Tang ${ }^{1,2 *}$ \\ ${ }^{1}$ South China Agricultural University, College of Agriculture, Guangzhou, 510642, Guangdong, China. \\ ${ }^{2}$ Ministry of Agriculture P.R. China, Scientific Observing and Experimental Station of Crop Cultivation in South China, Guangzhou, \\ 510642, Guangdong, China. *Corresponding author (tangxr@scau.edu.cn). \\ ${ }^{3}$ University of Agriculture, Department of Agronomy, Faisalabad, 38040 Pakistan. \\ ${ }^{4}$ Crops Research Institute, Guangdong Academy of Agricultural Sciences, Guangzhou, 510640, Guangdong, China.
}

Received: 11 December 2017; Accepted: 23 April 2018; doi:10.4067/S0718-58392018000200165

\begin{abstract}
Aromatic rice (Oryza sativa L. subsp. japonica Kato) is globally popular due to its pleasant aroma and enchanting flavor. 2-Acetyl-1-pyrroline (2-AP) is recognized as the only major flavoring compound in aromatic rice. Plant nutrition affects the production and accumulation of 2-AP in rice, but the effect of time-specific nutrient application during the developmental phases of rice on 2-AP has not yet been reported. Three $\mathrm{N}$ levels (N0: $0 \mathrm{~kg} \mathrm{ha}^{-1}, \mathrm{~N} 1: 30 \mathrm{~kg} \mathrm{ha}^{-1}$, and N2: 60 $\mathrm{kg} \mathrm{ha}^{-1}$ ) at the booting stage were applied to a popular aromatic rice $\mathrm{cv}$. Yungengyou 14, to assess the accumulation pattern of 2-AP, proline, and $\mathrm{N}$ as well as relationships among the investigated indices regarding 2-AP accumulation. Among all other plant parts, the highest $2 \mathrm{AP}$ contents were found in ear axes and flag leaves, i.e. $17.04 \%-18.26 \%$ and $14.37 \%$ $15.05 \%$ at 17 as well as $18.41 \%-22.74 \%$ and $14.38 \%-15.75 \%$ at $30 \mathrm{DAF}$ under all $\mathrm{N}-$ levels. Interestingly, $\mathrm{N}$ application at the booting stage also maintained higher proline and 2-AP contents in different plant tissues during the early grain filling stage. Hence additional $\mathrm{N}$ dose at booting stage could improve the grain aroma contents of aroma rice while considering the amount of $\mathrm{N}$ fertilizer added.
\end{abstract}

Key words: Aroma, Oryza sativa subsp. japonica, nitrogen, plant tissues, 2-AP.

\section{INTRODUCTION}

Fragrant rice (Oryza sativa L. subsp. japonica Kato) is globally appreciated among consumers and is in high demand because of its potent aromatic flavor (Hashemi et al., 2013; Ashraf and Tang, 2017). In aromatic rice, either the jasmine types of Thailand or the basmati types of Pakistan and India, 2-acetyl-1-pyrroline (2-AP) has been identified as the key aromatic compound and is recognized as a value added character for rice quality determination (Yang et al., 2008a; 2008b; Mathure et al., 2014; Ashraf et al., 2017). In addition to the roots, 2-AP can be detected in all aboveground plant tissues of the aromatic rice plant (Yoshihashi et al., 2002; Yoshihashi, 2002; Maraval et al., 2010). Interestingly, very low concentrations of 2-AP have also been detected in some non-aromatic rice varieties (Maraval et al., 2010).

Possible pathways for 2-AP biosynthesis have already been described in previous studies (Bradbury et al., 2008; Huang et al., 2008; Chen et al., 2008; Hashemi et al., 2013). Among these pathways, several reports have shown that proline constitutes the precursor for the formation of 2-AP in aromatic rice. Yoshihashi et al. (2002) further reported that the $\mathrm{N}$ 
source and the major precursor of 2-AP was proline, followed by glutamic acid and ornithine. Moreover, Adams and Kimpe (2007) confirmed that 1-pyrroline, a product of ornithine and proline, is the important precursor for the formation of 2-AP. Overall, these data indicate that proline is a very critical amino acid responsible for 2-AP biosynthesis in scented rice. However, the main part of the plant that accumulates proline and is a determinant of 2-AP accumulation in grains remains unidentified.

In addition, plant nutrition status also induces regulations in aroma contents in fragrant rice (Li et al., 2016; Mo et al., 2016; Lei et al., 2017). For instance, $\mathrm{N}$ also affects 2-AP formation in aromatic rice during its growth period (Ren et al., 2017). Furthermore, the soil $\mathrm{N}$ content directly affects rice aroma and the grain $\mathrm{N}$ content of brown rice (Yang et al., 2012). Thus, $\mathrm{N}$ fertilization is an effective method to regulate the 2-AP content and flavor of aromatic rice (Yoshihashi, 2005). However, the mechanism by which $\mathrm{N}$ application, especially at the booting stage, affects 2-AP synthesis and accumulation in rice and its relationship with different plant parts remains unknown.

Previous studies have indicated that 2-AP accumulates in different parts of aromatic rice, such as leaves, grains and stems (Yoshihashi, 2002; Maraval et al., 2010; Poonlaphdecha et al., 2012; Mo et al., 2015). However, the accumulation and the internal connections of 2-AP in these plant tissues remain poorly understood. Therefore, we have evaluated the effects of $\mathrm{N}$ application at the booting stage on 2-AP biosynthesis and its accumulation in different plant tissues and illustrated its relationships with proline content and total $\mathrm{N}$ contents. We also demonstrated how $\mathrm{N}$ management improves 2-AP content in aromatic rice cultivars.

\section{MATERIALS AND METHODS}

\section{Plant material and growth conditions}

A popular aromatic rice (Oryza sativa L. subsp. japonica), 'Yungengyou 14', was used as a planting material. Seeds were obtained from previously harvested early-season rice. The field experiment was conducted from July to December 2013 (late-season rice) at the Experimental Farm of the South China Agricultural University in Guangzhou, China. The experimental soil was sandy loam (Mo et al., 2015) containing $25.70 \mathrm{~g} \mathrm{~kg}^{-1}$ organic matter, $1.40 \mathrm{~g} \mathrm{~kg}^{-1}$ total N, $1.00 \mathrm{~g} \mathrm{~kg}^{-1}$ total $\mathrm{P}, 17.50 \mathrm{~g} \mathrm{~kg}^{-1}$ total $\mathrm{K}, 85.50 \mathrm{mg} \mathrm{kg}^{-1}$ available $\mathrm{N}, 25.10 \mathrm{mg} \mathrm{kg}^{-1}$ available $\mathrm{P}$, and $153.20 \mathrm{mg} \mathrm{kg}^{-1}$ available K. During the rice growing season, the mean temperature, average $\mathrm{RH}$, total precipitation and total sunshine hours were: $23.7^{\circ} \mathrm{C}$, $75.3 \%, 711.1 \mathrm{~mm}$, and $980.6 \mathrm{~h}$, respectively.

\section{Experimental designs and treatments}

Three $\mathrm{N}$ treatments were arranged in a randomized complete block design (RCBD) with three replicates, i.e. N0: 0 $\mathrm{kg} \mathrm{N} \mathrm{ha}^{-1}$ (control); $\mathrm{N} 1: 30 \mathrm{~kg} \mathrm{~N} \mathrm{ha}^{-1}$; and N2: $60 \mathrm{~kg} \mathrm{~N} \mathrm{ha}^{-1}$. The treatments were finalized based on our previous studies of early- and late-season rice during 2011 (data not shown). However, all three $\mathrm{N}$ treatments consisted of the same fertilizer dose as that applied at the basal and at the tillering stage. Before transplanting, $90 \mathrm{~kg} \mathrm{P}_{2} \mathrm{O}_{5} \mathrm{ha}^{-1}, 195 \mathrm{~kg} \mathrm{~K}_{2} \mathrm{O} \mathrm{ha}^{-1}$, and 90 $\mathrm{kg} \mathrm{N} \mathrm{ha}^{-1}$ were applied as basal fertilizer, whereas $30 \mathrm{~kg} \mathrm{~N} \mathrm{ha}^{-1}$ was added as tillering fertilizer $5 \mathrm{~d}$ after transplanting. Urea $(46 \% \mathrm{~N})$ was used as a $\mathrm{N}$ source. Except for the treatments under study, all other crop management practices (irrigations, pest, disease, and weed control) were uniform.

\section{Plant sample preparation and analytical methods}

The plants were sampled at two different stages: the early grain filling stage at which approximately $25 \%$ of grains had matured (17 d after flowering, $17 \mathrm{DAF}$ ), and the later grain filling stage at which approximately $80 \%$ of the grains had matured (30 d after flowering, $30 \mathrm{DAF}$ ). To obtain reliable data, 25 representative plants were collected from each treatment group at each sampling stage and carefully transported to the laboratory. The harvested plants were first thoroughly washed with running tap water and then with deionized water. The withered and yellow leaves and leaf sheaths were removed and discarded. The samples were then divided into various tissues, including the grains, ear axes, first internodes, flag leaf sheaths, flag leaves, second internodes, second leaf sheaths, second leaves, other internodes, other leaf sheaths and other leaves (other leaf sheaths and other leaves were not available at the second sampling stage). Five of the 25 samples were oven dried at $75^{\circ} \mathrm{C}$ to a constant weight and then ground into powders to measure the total $\mathrm{N}$ contents. The plant organs of the remaining 20 samples were divided into three parts to measure the proline and 2-AP contents. Before measuring the proline and 2-AP contents, the samples were stored at $-20{ }^{\circ} \mathrm{C}$. 
The total $\mathrm{N}$ content was digested as described by $\mathrm{Lu}(2000)$ and the digestion solution was then used to determine total N \% using the Kjeldahl method with a 2300 Kjeltec Analyzer Unit (Foss Tecator AB, Hilleroed, Denmark). The proline content was measured according to (Bates et al., 1973). The synchronization distillation and extraction method (SDE) combined with a GC-MS QP 2010 plus (Shimadzu Corporation, Kyoto, Japan) was used to measure the 2-AP content (Huang et al., 2012; Mo et al., 2015). Collidine (2,4,6-trimethylpyridine) (Sigma, St. Louis, Missouri, USA) was used as an internal standard. Ten grams of fresh plant samples of different parts were extracted; and the 2-AP level in the extraction solution was immediately measured using a GC-MS QP 2010 plus system after drying over sodium sulfate and filtering $(0.22 \mu \mathrm{m}$ filter paper, Shimadzu). The following GC-MS QP 2010 plus measurement conditions were employed: the gas chromatograph was equipped with an RTX-5MS (Shimadzu) silica capillary column $(30 \mathrm{~m} \times 0.32 \mathrm{~mm} \times 0.25 \mu \mathrm{m})$. High purity helium gas (99.99\%, Guangzhou Gases Co., Guangzhou, China) served as the carrier gas at a flow rate of 2.0 $\mathrm{mL} \mathrm{min}{ }^{-1}$. The temperature of the $\mathrm{GC}$ oven was $40{ }^{\circ} \mathrm{C}$, increased to $65^{\circ} \mathrm{C}$ at $2{ }^{\circ} \mathrm{C} \mathrm{min}{ }^{-1}$, held at $65{ }^{\circ} \mathrm{C}$ for $1 \mathrm{~min}$, increased to $220{ }^{\circ} \mathrm{C}$ at $10{ }^{\circ} \mathrm{C} \mathrm{min}-1$, and held at $220{ }^{\circ} \mathrm{C}$ for $10 \mathrm{~min}$. The ion source temperature was $200{ }^{\circ} \mathrm{C}$. Under these conditions, the retention time of 2-AP was $7.5 \mathrm{~min}$. The 2-AP contents are expressed as $\mathrm{ng} \mathrm{g}^{-1}$.

\section{Statistical analyses}

An ANOVA was performed and correlation coefficients were calculated using Statistix version 8 (Analytical software, Tallahassee, Florida, USA). All data on 2-AP, proline and total $\mathrm{N}$ are presented on a dry weight basis. The means were compared using the least significance difference (LSD) test at $\mathrm{P}<0.05$.

\section{RESULTS}

\section{2-acetyl-1-pyrroline accumulation in aromatic rice plants}

The 2-acetyl-1-pyrroline (2-AP) contents in various aromatic rice plant tissues are presented in Figure 1. The results for the three $\mathrm{N}$ application rates, two growth stages and all duplicates were pooled together to directly compare different parts of the aromatic rice plant. The average 2-AP contents ranged from 114.88 to $820.18 \mathrm{ng} \mathrm{g}^{-1}$. The 2-AP contents in different tissues of the plant ranked as follows: ear axes $>$ flag leaves $>$ second leaves $>$ first internodes $>$ grains $>$ flag leaf sheaths $>$ second leaf sheaths $>$ second internodes $>$ other leaves $>$ other internodes $>$ other leaf sheaths.

The 2-AP contents in the grains, flag leaves, second leaves, other leaf sheaths and other leaves significantly increased at $17 \mathrm{DAF}$ in the N1 group. The 2-AP contents in the grains, flag leaves, second internodes and other leaves were significantly increased in the $\mathrm{N} 2$ group, whereas the 2-AP contents in the flag leaf sheaths of this group were significantly decreased at 30 DAF. N1 significantly increased the 2-AP contents in the grains, ear axes, first internodes, flag leaves, second internodes, and other internodes but drastically decreased the 2-AP contents in the flag leaf sheaths at $30 \mathrm{DAF}$. Significant increases in the 2-AP contents in the flag leaf sheaths, flag leaves, second internodes, and second leaf sheaths were observed in the N2 group at $30 \mathrm{DAF}$. Furthermore the maximum distribution proportions of $2 \mathrm{AP}$ was found in ear axes and flag leaves, i.e. 17.04\%$18.26 \%$ and $14.37 \%-15.05 \%$ at 17 as well as $18.41 \%-22.74 \%$ and $14.38 \%-15.75 \%$ at 30 DAF (Table 1 ).

Figure 1. 2-Acetyl-1-pyrroline (2-AP) content among various parts of aromatic rice plants as means for the two growth stages (17 and $30 \mathrm{~d}$ after flowering).

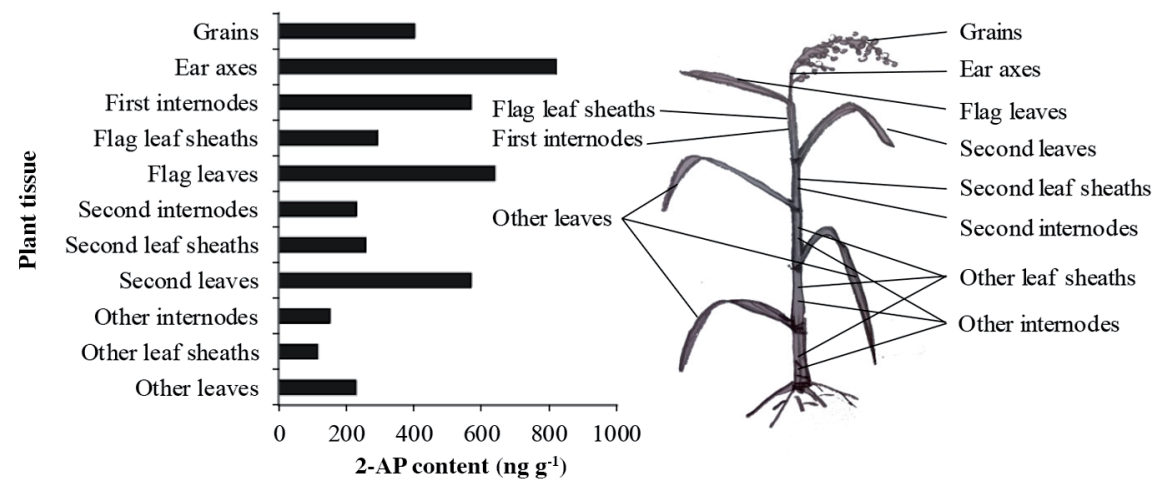


Table 1. 2-Acetyl-1-pyrroline content $\left(\mathrm{ng} \mathrm{g}^{-1}\right)$ in various plant tissues of aromatic rice at different $\mathrm{N}$ application rates at 17 and $30 \mathrm{~d}$ after flowering (DAF).

\begin{tabular}{|c|c|c|c|c|c|c|c|c|c|c|c|c|}
\hline \multirow[b]{2}{*}{ Plant tissue } & \multicolumn{6}{|c|}{$17 \mathrm{DAF}$} & \multicolumn{6}{|c|}{$30 \mathrm{DAF}$} \\
\hline & NO & $\mathrm{D}(\%)$ & N1 & $\mathrm{D}(\%)$ & $\mathrm{N} 2$ & $\mathrm{D}(\%)$ & No & $\mathrm{D}(\%)$ & N1 & $\mathrm{D}(\%)$ & $\mathrm{N} 2$ & $\mathrm{D}(\%)$ \\
\hline Grains & $317.00 \mathrm{c}$ & 8.22 & $423.25 \mathrm{a}$ & 9.41 & $357.08 \mathrm{~b}$ & 8.74 & $372.83 b$ & 9.41 & $478.81 \mathrm{a}$ & 11.02 & $458.42 \mathrm{ab}$ & 9.60 \\
\hline Ear axes & $703.96 \mathrm{a}$ & 18.26 & $766.22 \mathrm{a}$ & 17.04 & $710.89 \mathrm{a}$ & 17.39 & $872.80 \mathrm{~b}$ & 22.03 & $987.63 \mathrm{a}$ & 22.74 & $879.60 \mathrm{~b}$ & 18.41 \\
\hline First internodes & $440.29 \mathrm{a}$ & 11.42 & $422.33 \mathrm{a}$ & 9.39 & $461.85 \mathrm{a}$ & 11.30 & $601.77 \mathrm{c}$ & 15.19 & $722.07 b$ & 16.62 & $761.33 \mathrm{a}$ & 15.94 \\
\hline Flag leaf sheaths & $308.24 \mathrm{a}$ & 8.00 & $290.75 a$ & 6.47 & $212.80 \mathrm{~b}$ & 5.21 & $326.33 b$ & 8.24 & $212.43 c$ & 4.89 & $400.50 \mathrm{a}$ & 8.38 \\
\hline Flag leaves & $580.00 \mathrm{c}$ & 15.05 & $645.96 \mathrm{a}$ & 14.37 & $610.44 b$ & 14.93 & $569.53 c$ & 14.38 & $673.93 b$ & 15.51 & $752.67 \mathrm{a}$ & 15.75 \\
\hline Second internodes & $146.07 \mathrm{~b}$ & 3.79 & $187.77 \mathrm{ab}$ & 4.18 & $199.45 a$ & 4.88 & $233.53 \mathrm{c}$ & 5.90 & $270.23 b$ & 6.22 & $241.13 \mathrm{a}$ & 5.05 \\
\hline Second leaf sheaths & $236.02 \mathrm{a}$ & 6.12 & $189.49 a$ & 4.21 & $194.57 \mathrm{a}$ & 4.76 & $267.70 b$ & 6.76 & $256.70 b$ & 5.91 & $397.37 \mathrm{a}$ & 8.32 \\
\hline Second leaves & $468.91 b$ & 12.16 & $597.17 \mathrm{a}$ & 13.28 & $527.43 \mathrm{ab}$ & 12.90 & $591.27 \mathrm{ab}$ & 14.93 & $553.47 \mathrm{~b}$ & 12.74 & $672.00 \mathrm{a}$ & 14.07 \\
\hline Other internodes & $133.10 \mathrm{a}$ & 3.45 & $123.42 \mathrm{a}$ & 2.74 & $125.54 \mathrm{a}$ & 3.07 & $125.37 \mathrm{c}$ & 3.17 & $188.13 b$ & 4.33 & $214.63 \mathrm{a}$ & 4.49 \\
\hline Other leaf sheaths & $225.76 b$ & 5.86 & $255.56 \mathrm{a}$ & 5.68 & $207.93 b$ & 5.09 & - & & - & & - & \\
\hline Other leaves & $295.39 \mathrm{c}$ & 7.66 & $594.31 \mathrm{a}$ & 13.22 & $479.81 b$ & 11.74 & - & & - & & - & \\
\hline
\end{tabular}

Different letters indicate significant difference at $\mathrm{P}<0.05$ among different $\mathrm{N}$ application rates according to least significant difference (LSD) test.

N0: $0 \mathrm{~kg} \mathrm{~N} \mathrm{ha}^{-1}$; N1: $30 \mathrm{~kg} \mathrm{~N} \mathrm{ha}^{-1}$; N2: $60 \mathrm{~kg} \mathrm{~N} \mathrm{ha}^{-1}$; D: distribution proportion.

\section{Proline content in aromatic rice plants}

The proline contents in different plant tissues were significantly increased in the N1 (except for the ear axes and second internodes) and N2 (except for the grains, ear axes, flag leaves and other internodes) groups at 17 DAF. A substantial reduction in the proline content of flag leaves was identified for N1 at $30 \mathrm{DAF}$. The proline content in the grains, flag leaf sheaths, flag leaves, second leaf sheaths, and second leaves was significantly increased for N2 at 30 DAF. Furthermore, the lowest proline level was observed in the grain for both stages. The leaves contained the most proline, followed by leaf sheaths and internodes at 30 DAF. The proline content did not exhibit a consistent trend in different plant tissue at 17 DAF (Table 2).

\section{Total $\mathbf{N}$ content in scented rice plant}

At 17 DAF, a significant reduction was identified in the total $\mathrm{N}$ content in other internodes for both $\mathrm{N}$ levels (N1 and N2). Specifically, significant reduction in the total $\mathrm{N}$ content was identified in the second leaves (17 DAF), first internodes (30 $\mathrm{DAF}$ ), and other internodes (30DAF) for N1 but not for N2. Moreover, significant increases in the total N content in the ear axes were identified for $\mathrm{N} 1$, whereas a decrease was identified for $\mathrm{N} 2$ at $30 \mathrm{DAF}$. The total $\mathrm{N}$ content in other plant tissues did not significantly differ between the $\mathrm{N}$ treatments. At either stage, the leaves and the grains contained more total $\mathrm{N}$ than the leaf sheaths and internodes (Table 3).

Table 2. Proline content in various plant tissues of aromatic rice at different $\mathbf{N}$ application rates at 17 and $30 \mathrm{~d}$ after flowering (DAF).

\begin{tabular}{|c|c|c|c|c|c|c|c|c|}
\hline \multirow[b]{2}{*}{ Plant tissue } & \multicolumn{4}{|c|}{$17 \mathrm{DAF}$} & \multicolumn{4}{|c|}{$30 \mathrm{DAF}$} \\
\hline & No & N1 & $\mathrm{N} 2$ & Mean & NO & $\mathrm{N} 1$ & N2 & Mean \\
\hline & \multicolumn{4}{|c|}{$\mathrm{ng} \mathrm{g}^{-1}$} & \multicolumn{4}{|c|}{$-\mathrm{ng} \mathrm{g}^{-1}$} \\
\hline Grains & $6.308 b$ & $14.873 \mathrm{a}$ & $6.835 b$ & 9.339 & $3.604 b$ & $3.728 b$ & $5.359 \mathrm{a}$ & 4.230 \\
\hline Ear axes & $35.457 \mathrm{a}$ & $34.374 \mathrm{a}$ & $30.706 a$ & 33.512 & $26.317 \mathrm{a}$ & $24.180 \mathrm{a}$ & $26.742 \mathrm{a}$ & 25.746 \\
\hline First internodes & $27.729 \mathrm{c}$ & $56.116 \mathrm{a}$ & $42.804 b$ & 42.216 & $30.258 \mathrm{a}$ & $22.607 \mathrm{a}$ & $20.919 a$ & 24.595 \\
\hline Flag leaf sheaths & $28.367 \mathrm{~b}$ & $43.852 \mathrm{a}$ & $39.468 \mathrm{a}$ & 37.129 & $25.904 b$ & $26.565 b$ & $32.159 \mathrm{a}$ & 28.209 \\
\hline Flag leaves & $36.239 b$ & $50.566 \mathrm{a}$ & $33.147 \mathrm{~b}$ & 39.984 & $41.175 b$ & $31.293 \mathrm{c}$ & $55.652 \mathrm{a}$ & 42.706 \\
\hline Second internodes & $34.343 b$ & $43.531 b$ & $64.261 \mathrm{a}$ & 47.378 & $25.877 \mathrm{a}$ & $24.011 \mathrm{a}$ & $33.998 \mathrm{a}$ & 27.962 \\
\hline Second leaf sheaths & $22.362 b$ & $48.016 \mathrm{a}$ & $50.677 \mathrm{a}$ & 40.351 & $33.224 b$ & $45.692 \mathrm{ab}$ & $54.540 \mathrm{a}$ & 44.485 \\
\hline Second leaves & $29.430 b$ & $53.578 \mathrm{a}$ & $53.012 \mathrm{a}$ & 45.340 & $49.080 \mathrm{~b}$ & $55.225 b$ & $75.085 \mathrm{a}$ & 59.796 \\
\hline Other internodes & $36.323 b$ & $56.198 \mathrm{a}$ & $37.860 \mathrm{~b}$ & 43.461 & $35.038 \mathrm{a}$ & $30.298 \mathrm{a}$ & $29.785 a$ & 31.707 \\
\hline Other leaf sheaths & $50.238 b$ & $85.231 \mathrm{a}$ & $76.995 \mathrm{a}$ & 70.821 & - & - & - & - \\
\hline Other leaves & $31.786 b$ & $62.610 \mathrm{a}$ & $68.559 \mathrm{a}$ & 54.318 & - & - & - & - \\
\hline
\end{tabular}

Different letters indicate a significant difference at $\mathrm{P}<0.05$ among different $\mathrm{N}$ application rates according to least significant difference (LSD) test. N0: $0 \mathrm{~kg} \mathrm{~N} \mathrm{ha}^{-1} ; \mathrm{N} 1: 30 \mathrm{~kg} \mathrm{~N}^{-1} ; \mathrm{N} 2: 60 \mathrm{~kg} \mathrm{~N} \mathrm{ha}^{-1}$. 
Table 3. Total $N$ content in various plant tissues of aromatic rice at different $N$ application rates (\%) after 17 and $30 \mathrm{~d}$ after flowering (DAF).

\begin{tabular}{|c|c|c|c|c|c|c|c|c|}
\hline \multirow[b]{2}{*}{ Plant tissue } & \multicolumn{4}{|c|}{$17 \mathrm{DAF}$} & \multicolumn{4}{|c|}{$30 \mathrm{DAF}$} \\
\hline & NO & N1 & $\mathrm{N} 2$ & Mean & NO & N1 & N2 & Mean \\
\hline & & $\%$ & & - & & - & & \\
\hline Grains & $1.3148 \mathrm{a}$ & $1.4834 \mathrm{a}$ & $1.1125 \mathrm{a}$ & 1.3036 & $0.8142 \mathrm{a}$ & $0.7336 \mathrm{a}$ & $0.8407 \mathrm{a}$ & 0.7961 \\
\hline Ear axes & $0.5390 \mathrm{a}$ & $0.3472 \mathrm{a}$ & $0.6095 \mathrm{a}$ & 0.4986 & $0.3596 \mathrm{~b}$ & $0.6072 \mathrm{a}$ & $0.2380 \mathrm{c}$ & 0.4016 \\
\hline First internodes & $0.5629 a$ & $0.1834 \mathrm{a}$ & $0.3709 \mathrm{a}$ & 0.3724 & $0.3324 \mathrm{a}$ & $0.0992 b$ & $0.1617 \mathrm{ab}$ & 0.1978 \\
\hline Flag leaf sheaths & $0.9565 \mathrm{a}$ & $0.3273 \mathrm{a}$ & $0.6424 \mathrm{a}$ & 0.6421 & $0.1951 \mathrm{a}$ & $0.4894 \mathrm{a}$ & $0.5592 \mathrm{a}$ & 0.4146 \\
\hline Flag leaves & $1.9267 \mathrm{a}$ & $1.9051 \mathrm{a}$ & $2.8482 \mathrm{a}$ & 2.2267 & $0.5208 \mathrm{a}$ & $0.9360 \mathrm{a}$ & $0.9862 \mathrm{a}$ & 0.8143 \\
\hline Second internodes & $0.3432 \mathrm{a}$ & $0.2976 \mathrm{a}$ & $0.2949 \mathrm{a}$ & 0.3119 & $0.2950 \mathrm{ab}$ & $0.5293 \mathrm{a}$ & $0.2244 b$ & 0.3496 \\
\hline Second leaf sheaths & $0.3098 \mathrm{a}$ & $0.4499 \mathrm{a}$ & $0.5512 \mathrm{a}$ & 0.4370 & $0.3520 \mathrm{a}$ & $0.5714 \mathrm{a}$ & $0.3449 \mathrm{a}$ & 0.4228 \\
\hline Second leaves & $1.8193 \mathrm{a}$ & $0.9881 b$ & $2.0030 \mathrm{a}$ & 1.6035 & $0.4848 \mathrm{a}$ & $0.5752 \mathrm{a}$ & $1.0317 \mathrm{a}$ & 0.6973 \\
\hline Other internodes & $0.6632 \mathrm{a}$ & $0.2398 b$ & $0.2791 \mathrm{~b}$ & 0.3940 & $0.2640 \mathrm{a}$ & $0.1016 b$ & $0.1997 \mathrm{ab}$ & 0.1884 \\
\hline Other leaf sheaths & $0.4263 \mathrm{a}$ & $0.4177 \mathrm{a}$ & $0.8307 \mathrm{a}$ & 0.5582 & - & - & - & - \\
\hline Other leaves & $1.2339 \mathrm{a}$ & $0.8662 \mathrm{a}$ & $1.1213 \mathrm{a}$ & 1.0738 & - & - & - & - \\
\hline
\end{tabular}

Different letters indicate a significant difference at $\mathrm{P}<0.05$ among different $\mathrm{N}$ application rates according to least significant difference (LSD) test. N0: 0 kg N ha' ${ }^{-1}$ N1: $30 \mathrm{~kg} \mathrm{~N} \mathrm{ha}^{-1}$; $2: 60 \mathrm{~kg} \mathrm{~N}^{-1}$.

Correlation between the 2-AP, proline, and total $\mathrm{N}$ contents in different plant parts at different stages

A significant positive correlation was observed between the 2-AP contents in grains at $30 \mathrm{DAF}$ and the 2-AP contents in grains, flag leaves, second leaves, and other leaves at 17 DAF. Moreover, the 2-AP contents in the grains at $30 \mathrm{DAF}$ exhibited a significant positive correlation with the proline contents of the first internodes, flag leaf sheaths, second internodes, second leaf sheaths, second leaves, other leaf sheaths, and other leaves at 17 DAF. Moreover, the 2-AP contents of grains at $30 \mathrm{DAF}$ exhibited a significant negative correlation with the total $\mathrm{N}$ content in other internodes at 30 DAF (Table 4).

Table 4. Correlation of 2-acetyl-1-pyrroline (2-AP) content, proline content, and total $\mathrm{N}$ contents in different parts of the plant at different stages.

\begin{tabular}{|c|c|c|c|}
\hline Plant tissues & 2-AP content & Proline content & Total N content \\
\hline \multicolumn{4}{|l|}{$17 \mathrm{DAF}$} \\
\hline Grains & $0.7741^{*}$ & 0.5955 & 0.1092 \\
\hline Ear axes & 0.3356 & -0.4450 & -0.0970 \\
\hline First internodes & -0.0880 & $0.7320 *$ & -0.5017 \\
\hline Flag leaf sheaths & -0.2914 & $0.7540 *$ & -0.4698 \\
\hline Flag leaves & $0.7170 *$ & 0.5894 & -0.0380 \\
\hline Second internodes & 0.4938 & $0.7170 *$ & -0.0648 \\
\hline Second leaf sheaths & -0.5514 & $0.6690 *$ & 0.5791 \\
\hline Second leaves & $0.7540 *$ & $0.8280 * *$ & -0.4039 \\
\hline Other internodes & -0.2078 & 0.4694 & -0.6634 \\
\hline Other leaf sheaths & 0.2643 & $0.7290 *$ & 0.1381 \\
\hline Other leaves & $0.8140 * *$ & $0.8420 * *$ & -0.4942 \\
\hline \multicolumn{4}{|l|}{$30 \mathrm{DAF}$} \\
\hline Grains & 1.0000 & 0.2107 & -0.3185 \\
\hline Ear axes & 0.4754 & -0.5815 & 0.2190 \\
\hline First internodes & 0.6411 & -0.5385 & -0.4674 \\
\hline Flag leaf sheaths & -0.3071 & 0.1204 & 0.5636 \\
\hline Flag leaves & 0.5945 & -0.1343 & 0.4574 \\
\hline Second internodes & 0.5061 & -0.1567 & 0.5214 \\
\hline Second leaf sheaths & 0.1544 & 0.3435 & 0.0324 \\
\hline Second leaves & -0.0104 & 0.2596 & 0.2938 \\
\hline Other internodes & 0.6144 & -0.3308 & $-0.726^{*}$ \\
\hline
\end{tabular}

Significant correlations at $* \mathrm{P}<0.05, * * \mathrm{P}<0.01$. DAF: Days after flowering. 


\section{DISCUSSION}

The effect of $\mathrm{N}$ on the 2-AP content in rice remains controversial. In this study, we attempted to delineate the relationships between $\mathrm{N}$ and the 2-AP contents in various parts of the rice plant, including the grains. Our results demonstrate that $\mathrm{N}$ feeding (at the booting stage) improved the 2-AP contents in different parts of the rice plant. Previous studies have shown that the 2-AP content varies by planting site, plant environmental condition, genotype, cultivar, and even the part of the plant (Yoshihashi, 2002; Mathure et al., 2014; Mo et al., 2017). Maraval et al. (2010) detected the levels of 2-AP in the leaves, stems, panicles and grains of three different scented rice cultivars harvested from three different sites in France and revealed that the 2-AP content ranged from 287.3 to $638.3 \mathrm{ng} \mathrm{g}^{-1}$ for grains, 397.9 to $404.8 \mathrm{ng} \mathrm{g}^{-1}$ for panicles, 271.6 to $317.6 \mathrm{ng} \mathrm{g}^{-1}$ for stems, and $981.3 \mathrm{ng} \mathrm{g}^{-1}$ to $1263.0 \mathrm{ng} \mathrm{g}^{-1}$ for leaves. Moreover, Poonlaphdecha et al. (2012) reported that the content of 2-AP ranged from 4276.60 to $6168.80 \mathrm{ng} \mathrm{g}^{-1}$ in leaves and from 592.2 to $997.8 \mathrm{ng} \mathrm{g}^{-1}$ in grains. Here, we investigated the different parts of the plant in more detail, and the results revealed that the average 2-AP content ranged from $114.87 \mathrm{ng} \mathrm{g}^{-1}$ for other leaf sheaths to $820.18 \mathrm{ng} \mathrm{g}^{-1}$ for ear axes (Figure 1).

In addition, our study showed that the concentration of 2-AP in different plant parts ranked as follows: Ear axes $>$ flag leaves $>$ second leaves $>$ first internodes $>$ grains $>$ flag leaf sheaths $>$ second leaf sheaths $>$ second internodes $>$ other leaves $>$ other internodes $>$ other leaf sheaths. The ear axes accumulated the highest 2-AP contents (Figure 1), which contradicts the results of previous studies (Maraval et al., 2010; Poonlaphdecha et al., 2012). Moreover, we found that 2-AP contents in grains continued to increase from 17 DAF to 30 DAF. In contrast, Goufo et al. (2010) reported that the 2-AP contents of fragrant rice grains decreased as the rice matured for both aromatic rice cultivars 'Guixiangzhan' and 'Peizaruanxiang', and this difference was primarily attributed to the genotype.

To further elucidate the effect of $\mathrm{N}$ application on 2-AP accumulation, we found that the effect of $\mathrm{N}$ application differed by plant tissue, and this result corroborates those reported by Yoshihashi (2005), who reported that the aroma of grains depends on the $\mathrm{N}$ application rates. Here, we confirmed that applying additional $\mathrm{N}$ fertilizer (30 and $\left.60 \mathrm{~kg} \mathrm{~N} \mathrm{ha}^{-1}\right)$ at the booting stage increased the 2-AP contents of grains. In addition to the 2-AP contents of grains, we also revealed that the 2-AP contents in flag leaves, second leaves, other leaf sheaths and other leaves significantly increased in the N1 group at 17 DAF. Moreover, the 2-AP contents of flag leaves, second internodes and other leaves significantly increased in the N2 group, whereas the 2-AP contents in flag leaf sheaths significantly decreased at $30 \mathrm{DAF}$. Additionally, N1 significantly increased the 2-AP contents of ear axes, first internodes, flag leaves, second internodes, and other internodes but drastically decreased the 2-AP contents of flag leaf sheaths at $30 \mathrm{DAF}$. Furthermore, a significant increase in the 2-AP contents of flag leaf sheaths, flag leaves, second internodes, and second leaf sheaths was observed for N2 at 30 DAF (Table 1). A significant positive correlation between the 2-AP contents in grains at $30 \mathrm{DAF}$ and 2-AP contents in grains, flag leaves, second leaves, and other leaves was also observed at 17 DAF (Table 4). Overall, we concluded that applying additional N fertilizer (30 and $60 \mathrm{~kg} \mathrm{~N} \mathrm{ha}^{-1}$ ) at the booting stage increased the 2-AP contents in grains, mainly by increasing the 2-AP contents in grains, flag leaves, second leaves, and other leaves at 17 DAF.

Yang et al. (2012) found that the aroma of brown rice directly correlated with the total $\mathrm{N}$ and proline contents. Accordingly, we found that N1 and N2 increased the proline content of grains (Table 2). Moreover, the 2-AP content in grains positively correlated with the proline content in many parts of the plant at $17 \mathrm{DAF}$ and almost half of the plant tissues at $30 \mathrm{DAF}$ (Table 4). In addition, the 2-AP content of grains negatively correlated with the total $\mathrm{N}$ contents of grains at $30 \mathrm{DAF}$, but $\mathrm{N} 1$ and $\mathrm{N} 2$ did not affect the grain $\mathrm{N}$ content. Nevertheless, the total $\mathrm{N}$ contents of many parts of the plant positively and negatively correlated with the grain 2-AP content at 30 DAF and 17 DAF, respectively (Table 4). Overall, applying additional $\mathrm{N}$ at the booting stage increased the proline content, particularly the proline content at 17 DAF, and consequently improved the aroma.

In general, 2-AP accumulates in aromatic rice via the proline conversion pathway, thus, the fragrance of 'Basmati' - and 'Jasmine'-type rice cultivars is due to the generation of 2-acetyl-1-pyrroline from proline via $\triangle 1$-pyrroline when betaine aldehyde dehydrogenase gene (BAD2) is inactive or the generation of $\gamma$-amino butyric acid (GABA) when BAD2 is active (Bradbury et al., 2008). Alternatively, the $\Delta 1$-pyrroline reacts with the acetyl group, which is most likely produced by reacting with acetyl-CoA or acetaldehyde in either a chemical or enzymatic reaction, may produce aroma (Costello et al., 2001). Additionally, detailed precursor studies revealed that the formation of 2-AP in Bacillus cereus proceeds via the acetylation of $\Delta 1$-pyrroline (Adams and Kimpe, 2007). Thus, the increased free proline content in flag leaves and the grains of aromatic rice were expected to lead to the synthesis of 2-AP in brown rice (Krasensky and Jonak, 2012). 
Therefore, the application of $\mathrm{N}$ fertilizer contributed to the higher proline contents in the first internodes, flag leaf sheaths, second internodes, second leaf sheaths, second leaves, other leaf sheaths, and other leaves at 17 DAF, which ultimately resulted in 2-AP levels in grains.

However, pyrroline-5-carboxylic acid (Huang et al., 2008; Wu et al., 2009; Hashemi et al., 2013), which is synthesized by three enzymes, proline dehydrogenase, ornithine aminotransferase, and $\Delta 1$-pyrroline-5-carboxylic acid synthase, is another direct precursor of 2-AP (Wu et al., 2009). Huang et al. (2008) compared $\Delta 1$-pyrroline-5-carboxylate synthesizing enzymes in aromatic and non-aromatic rice cultivars and reported that $\Delta 1$-pyrroline-5-carboxylic acid synthase was the key enzyme leading to the formation of $\Delta 1$-pyrroline-5-carboxylic acid from glutamate that reacts directly with methylglyoxal to form 2-AP in aromatic rice (Hashemi et al., 2013). A similar pathway was identified in aromatic vegetable soybean (Glycine max L.) in a previous study (Wu et al., 2009). Although Yoshihashi et al. (2002) reported that the $\mathrm{N}$ source of 2-AP was proline, proline accumulation is measured based on the balance between biosynthesis and catabolism (Szabados and Savouré, 2010). Glutamate is reduced to glutamate-semialdehyde and then spontaneously converted to $\Delta 1$ pyrroline-5-carboxylic acid, which is then reduced to proline by proline dehydrogenase and $\Delta 1$-pyrroline-5-carboxylate dehydrogenase to glutamate (Krasensky and Jonak, 2012). Overall, glutamate also appears to be an essential substance for 2-AP formation (Fitzgerald et al., 2010). Furthermore, glutamate is an important metabolite of N. Thus, the nitrate is assimilated or transported after the application of $\mathrm{N}$ fertilizer to further increase the level of glutamate (Xu et al., 2012). This mechanism may be responsible for the increase in the 2-AP content in grains in response to the application of $\mathrm{N}$ fertilizer (30 and $\left.60 \mathrm{~kg} \mathrm{~N} \mathrm{ha}^{-1}\right)$ at the booting stage.

\section{CONCLUSION}

Overall, the 2-acetyl-1-pyrroline (2-AP) contents in different parts of the plant were detected as: Ear axes $>$ flag leaves $>$ second leaves $>$ first internodes $>$ grains $>$ flag leaf sheaths $>$ second leaf sheaths $>$ second internodes $>$ other leaves $>$ other internodes $>$ other leaf sheaths. The application of additional $\mathrm{N}$ improved the 2-AP contents of grains, flag leaves, second leaves, and other leaves and improved the proline content in grains and other parts of the plant, especially during the early grain filling stage. The maximum 2AP proportions were detected in ear axes and flag leaves i.e., 17.04\%-18.26\% and $14.37 \%-15.05 \%$ at $17 \mathrm{~d}$ after flowering (DAF) and $18.41 \%-22.74 \%$ and $14.38 \%-15.75 \%$ at 30 DAF. This study may provide application times for specific $\mathrm{N}$ management in order to further improve the aroma, flavor and quality of aromatic rice. Nevertheless, future studies should delineate genotypic differences among different plant tissues regarding 2-AP accumulation and the accumulation pattern in rice.

\section{ACKNOWLEDGEMENTS}

This study was supported by National Natural Science Foundation of China (31271646), Natural Science Foundation of Guangdong Province (8151064201000017), Agricultural Research Projects of Guangdong Province (2011 AO20202001), National Natural Science Foundation for Young Scientists (31601244), Natural Science Foundation of Guangdong Province (8151064201000017) and Agricultural Standardization Project of Guangdong Province (4100F10003).

\section{REFERENCES}

Adams, A., and Kimpe, D.N. 2007. Formation of pyrazines and 2-acetyl-1-pyrroline by Bacillus cereus. Food Chemistry 101(3):1230-1238.

Ashraf, U., Kanu, A.S., Deng, Q., Mo,Z., Pan, S., Tian, H., et al. 2017. Lead (Pb) toxicity; physio-biochemical mechanisms, grain yield, quality, and pb distribution proportions in scented rice. Frontiers in Plant Science 8:1-17. doi:10.3389/fpls.2017.00259.

Ashraf, U., and Tang, X. 2017. Yield and quality responses, plant metabolism and metal distribution pattern in aromatic rice under lead $(\mathrm{Pb})$ toxicity. Chemosphere 176:141-155.

Bates, L.S., Waldren, R.P., and Teare, D. 1973. Rapid determination of free proline for water stress studies. Plant and Soil 39(1):205-207.

Bradbury, L.M., Gillies, S.A., Brushett, D.J., Waters, D.L., and Henry, R.J. 2008. Inactivation of an aminoaldehyde dehydrogenase is responsible for fragrance in rice. Plant Molecular Biology 68(4-5):439-449. 
Chen, S., Yang, Y., Shi, W., Ji, Q., He, F., Zhang, Z., et al. 2008. Badh2, encoding betaine aldehyde dehydrogenase, inhibits the biosynthesis of 2-acetyl-1-pyrroline, a major component in rice fragrance. The Plant Cell 20(7):1850-1861.

Costello, P.J., Lee, T.H., and Henschke, P. 2001. Ability of lactic acid bacteria to produce N-heterocycles causing mousy offflavour in wine. Australian Journal of Grape and Wine Research 7(3):160-167.

Fitzgerald, T.L., Waters D.L.E., Brooks L.O., and Henry, R.J. 2010. Fragrance in rice (Oryza sativa) is associated with reduced yield under salt treatment. Environmental and Experimental Botany 68(3):292-300.

Goufo, P., Duan, M., Wongpornchai, S., and Tang, X. 2010. Some factors affecting the concentration of the aroma compound 2-acetyl-1-pyrroline in two fragrant rice cultivars grown in South China. Frontiers of Agriculture in China 4(1):1-9.

Hashemi, F.G., Rafii, M.Y., Ismail, M.R., Mahmud, T.M.M., Rahim, H.A., Asfaliza, R., et al. 2013. Biochemical, genetic and molecular advances of fragrance characteristics in rice. Critical Reviews in Plant Sciences 32(6):445-457.

Huang, Z.L., Tang, X.R., Wang, Y.L., Chen, M.J., Zhao, Z.K. Duan, M.Y., et al. 2012. Effects of increasing aroma cultivation on aroma and grain yield of aromatic rice and their mechanism. Scientia Agricultura Sinica 45(6):1054-1065.

Huang, T.C., Teng, C.S., Chang, J.L., Chuang, H.S., Ho, C.T., and Wu, M.L. 2008. Biosynthetic mechanism of 2-acetyl-1pyrroline and its relationship with $\Delta 1$-pyrroline-5-carboxylic acid and methylglyoxal in aromatic rice (Oryza sativa L.) callus. Journal of Agricultural and Food Chemistry 56(16):7399-7404.

Krasensky, J., and Jonak, C. 2012. Drought, salt, and temperature stress-induced metabolic rearrangements and regulatory networks. Journal of Experimental Botany 63(4):1593-1608.

Lei, S., Wang, C., Ashraf, U., Mo, Z., Nawaz, M., Ashraf, I., et al. 2017. Exogenous application of mixed micro-nutrients improves yield, quality, and 2-acetyl-1-pyrroline. Applied Ecology and Environmental Research 15(3):1097-1109.

Li, M., Ashraf, U., Tian, H., Mo,Z., Pan, S., Anjum, S.A., et al. 2016. Manganese-induced regulations in growth, yield formation, quality characters, rice aroma and enzyme involved in 2-acetyl-1-pyrroline biosynthesis in fragrant rice. Plant Physiology and Biochemistry 103:167-175.

Lu, R.K. 2000. Methods of soil and agro-chemical analysis. p. 2-14. China Agricultural Science and Technology Press, Beijing, China (in Chinese).

Maraval, I., Sen, K., Agrebi, A., Menut, C., Morere, A., Boulanger, R., et al. 2010. Quantification of 2-acetyl-1-pyrroline in rice by stable isotope dilution assay through headspace solid-phase micro-extraction coupled to gas chromatography-tandem mass spectrometry. Analytica Chimica Acta 675(2):148-155.

Mathure, S.V., Jawali, N., Thengane, R.J., and Nadaf, A.B. 2014. Comparative quantitative analysis of headspace volatiles and their association with $B A D H 2$ marker in non-basmati scented, basmati and non-scented rice (Oryza sativa L.) cultivars of India. Food Chemistry 142:383-391.

Mo, Z., Huang, J., Xiao, D., Ashraf, U., Duan, M., Pan, S., et al. 2016. Supplementation of 2-Ap, Zn and La improves 2-acetyl1-pyrroline concentrations in detached aromatic rice panicles in vitro. PLOS ONE 11(2):e0149523. doi:10.1371/journal. pone. 0149523 .

Mo, Z., Lei, S., Ashraf, U., Khan, I., Li, Y., Pan, S., et al. 2017. Silicon fertilization modulates 2-acetyl-1-pyrroline content, yield formation and grain quality of aromatic rice. Journal of Cereal Science 75:17-24.

Mo, Z., Li, W., Pan, S.G., Fitzgerald, T.L., Xiao, F., Tang, Y., et al. 2015. Shading during the grain filling period increases 2-acetyl-1-pyrroline content in fragrant rice. Rice 8:9. doi:10.1186/s12284-015-0040-y.

Poonlaphdecha, J., Maraval, I., Roques, S., Audebert, A., Boulanger, R., Bry, X., et al. 2012. Effect of timing and duration of salt treatment during growth of a fragrant rice variety on yield and 2-Acetyl-1-pyrroline, proline, and GABA levels. Journal of Agricultural and Food Chemistry 60(15):3824-3830.

Ren, Y., Ashraf, U., He, L.X., Mo, Z.W., Wang, F., Wan, X.C., et al. 2017. Irrigation and nitrogen management practices affect grain yield and 2-acetyl-1-pyrroline content in aromatic rice. Applied Ecology and Environmental Research 15(4):1447-1460.

Szabados, L., and Savouré, A. 2010. Proline: a multifunctional amino acid. Trends in Plant Science 15(2):89-97.

Wu, M.L., Chou, K.L., Wu, C.R., Chen, J.K., and Huang, T.C. 2009. Characterization and the possible formation mechanism of 2-acetyl-1-pyrroline in aromatic vegetable soybean (Glycine max L.) Journal of Food Science 74(5):192-197.

Xu, G., Fan, X., and Miller, A.J. 2012. Plant nitrogen assimilation and use efficiency. Annual Review of Plant Biology 63:153-182.

Yang, D.S., Lee, K.S., Jeong, O.Y., Kim, K.J., and Kays, S.J. 2008a. Characterization of volatile aroma compounds in cooked black rice. Journal of Agricultural and Food Chemistry 56(1):235-240.

Yang, D.S., Shewfelt, R.L., Lee, K.S., and Kays, S.J. 2008b. Comparison of odor-active compounds from six distinctly different rice flavor types. Journal of Agricultural and Food Chemistry 56(8):2780-2787.

Yang, S., Zou, Y., Liang, Y., Xia, B., Liu, S., Ibrahim, M., et al. 2012. Role of soil total nitrogen in aroma synthesis of traditional regional aromatic rice in China. Field Crops Research 125:151-160.

Yoshihashi, T. 2002. Quantitative analysis on 2-acetyl-1-pyrroline of an aromatic rice by stable isotope dilution method and model studies on its formation during cooking. Journal of Food Science 67(2):619-622.

Yoshihashi, T.2005. Does drought condition induce the aroma quality of aromatic rice? News Letter for International Collaboration 45. p. 4. Japan International Research Centre for Agricultural Science (JIRCAS). Food Science and Technology Division, Tsukuba, Japan.

Yoshihashi, T., Huong, N.T.T., and Inatomi, H. 2002. Precursors of 2-acetyl-1-pyrroline, a potent flavor compound of an aromatic rice variety. Journal of Agricultural and Food Chemistry 50(7):2001-2004. 